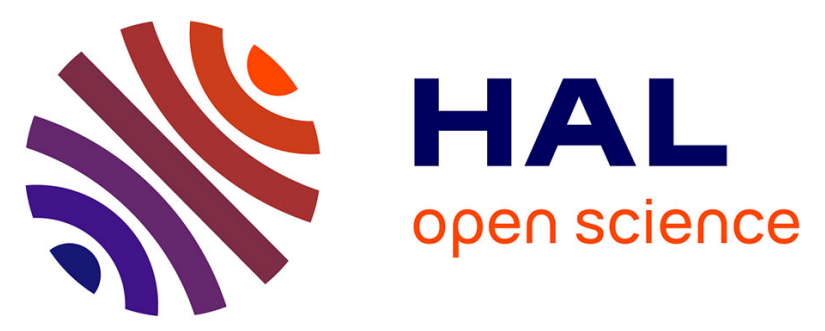

\title{
Microbiota dysbiosis induced by defect of paneth cells triggers visceral hypersensitivity in mice
}

\author{
Ambre Riba, Maïwenn Olier, Sonia Lamandé, Corinne Lencina, Valérie \\ Alquier-Bacquié, Cherryl Harkat, Marion Gillet, Marine Baron, Caroline \\ Sommer, Virginie Mallet, et al.
}

\section{To cite this version:}

Ambre Riba, Maïwenn Olier, Sonia Lamandé, Corinne Lencina, Valérie Alquier-Bacquié, et al.. Microbiota dysbiosis induced by defect of paneth cells triggers visceral hypersensitivity in mice. The Neonatal Window of Opportunity, Early Priming for Life, Herrenhausen Conference, Dec 2016, Hanovre, Germany. hal-01605506

\section{HAL Id: hal-01605506 https://hal.science/hal-01605506}

Submitted on 5 Jun 2020

HAL is a multi-disciplinary open access archive for the deposit and dissemination of scientific research documents, whether they are published or not. The documents may come from teaching and research institutions in France or abroad, or from public or private research centers.
L'archive ouverte pluridisciplinaire HAL, est destinée au dépôt et à la diffusion de documents scientifiques de niveau recherche, publiés ou non, émanant des établissements d'enseignement et de recherche français ou étrangers, des laboratoires publics ou privés. 


\author{
Abstract Title (171) \\ MICROBIOTA DYSBIOSIS INDUCED BY DEFECT OF ENTERIC ANTIMICROBIAL \\ ACTIVITY TRIGGERS VISCERAL HYPERSENSITIVITY IN YOUNG ADULT MICE
}

\title{
A short description of your research project (3000)
}

Our research project focuses on early and long course consequences of adverse events during perinatal period on intestinal barrier functions and immune system maturation and education. Indeed, perinatal period has been identified as a critical window for intestinal barrier and immune system establishment leading to an appropriate relationship between host and intestinal content i.e. homeostasis. Adverse events during this period might be responsible for disestablishment of host - microbiota relationship responsible for various diseases where an inappropriate host immune response toward luminal content has been identified. Luminal content is represented by food and microbial antigens. A rupture of tolerance toward microbiota has been observed in organic (inflammatory bowel diseases) and functional (irritable bowel syndrome) gastrointestinal disorders whereas during food intolerance, dietary factors are the target of the exacerbated immune response.

We address the consequences of adverse events during perinatal period on intestinal barrier functionality and immune response in different model challenged with stress, chemical or infections within the framework of collaborations.

We developed an expertise in the field of intestinal barrier, immune system and microbiota analysis in adult but also in young rodents. Concerning intestinal barrier, we develop experimental protocols to measure intestinal permeability in vivo and ex vivo, enteric antimicrobial peptides expression and antimicrobial assay toward commensal bacteria, visceral sensitivity in response to colorectal distension, immune response associated to intestinal epithelium. Regarding immune system, we perform not only immune cells characterization but also evaluation of their functionality.

Recently, a growing body of evidence highlighted the tight link between immune response and metabolism named immuno-metabolism. Metabolic disorders including type 2 diabetes and obesity are characterized by a low grade inflammation, intestinal hyper-permeability and microbiota dysbiosis. Within the framework of collaboration, we included the consequences of adverse events during perinatal period on metabolism at adulthood. 


\section{Abstract of the project you want to present}

A. Riba ${ }^{1}$, M. Olier ${ }^{1}$, S. Lacroix-Lamandé ${ }^{2}$, C. Lencina ${ }^{1}$, V. Bacquié ${ }^{1}$, C. Harkat $^{1}$, M. Gillet ${ }^{1}$, M. Baron ${ }^{1}$, C. Sommer ${ }^{1}$, V. Mallet ${ }^{1}$, C. Salvador-Cartier ${ }^{1}$, F. Laurent ${ }^{2}$, V. Théodorou ${ }^{1}$, S. Ménard ${ }^{1}$.

${ }^{1}$ INRA, ToxAlim (Research Centre in Food Toxicology), team Neuro-Gastroenterology and Nutrition, Toulouse, France

2 Equipe Apicomplexes et Immunité Mucosale (AIM), UMR 1282 INRA/UniversitéInfectiologie et Santé Publique (ISP), Centre INRA Val de Loire, Nouzilly, FRANCE

Paneth cell-derived antimicrobial peptides like lysozyme provide antibacterial protection and maintain intestinal homeostasis. We aimed to analyze the consequences of altered Paneth cells function on fecal antimicrobial activity, intestinal homeostasis and visceral sensitivity at adulthood. In 50-days old Sox $9^{\text {flox/flox }}$-vil-Cre female mice, absence of Paneth increased fecal population of Enterobacteriaceae associated to visceral hypersensitivity. Daily gavage of conventional adult mice with commensal E. coli, induced visceral hypersensitivity. Occurrence of adverse events during neonatal period impairs intestinal homeostasis establishment. Maternal separation (MS) is a well described rodent model of psychological stress characterized by a decrease of intestinal secretory cells and visceral hypersensitivity mimicking what we observed in Sox $9^{\text {flox/flox }}$-vil-cre mice. We wondered if in this model we also observed a dysbiosis in favor of Enterobacteriaceae. Mice submitted to MS, presented a defect of fecal antimicrobial activity associated with a fecal overgrowth of Enterobacteriaceae. Furthermore, this antimicrobial defect and its consequences on visceral sensitivity were prevented by oral administration of lysozyme. Our results show that a defect of enteric antimicrobial functions leads to microbiota dysbiosis in favor of Enterobacteriaceae responsible for visceral hypersensitivity providing new mechanistic insights in maternal separation-induced visceral hypersensitivity. 


\section{Short tabular CV}

Ambre RIBA

E-mail: ariba@ukaachen.de

\section{Current Position}

Post-Doctoral Position in intestinal physiology and infection, UNIKLINIK, Medizinische Mikrobiologie, Aachen, Deutschland, "Consequences of early infection on intestinal homeostasis at adulthood in mice», DFG Grant), team leader: Pr Mathias Hornef (since April 2015)

\section{Education}

o 2012-2015: PhD in intestinal physiology, INRA Toxalim, Equipe NGN (NeuroGastroentérologie et Nutrition), Toulouse, France, «Consequences of early life stress on intestinal homeostasis and response toward microbiota at adulthood », Bourse DGER école d'ingénieur de Purpan grant, scientific directors: S. Ménard et V. Théodorou (defended in February 2015)

o 2010-2011: Master's degree in food science and human nutrition (2011), ONIRIS University of Nantes, Nantes, France.

o "Impact of antibiotic therapy in rat on intestinal barrier et visceral sensitivity at different ages of life", scientific director: Dr H. Eutamene, ToxAlim, INRA, Toulouse, France.

o 2010: Master's degree in Nutrition \& Health - Food Technology, ETH of Zurich, Switzerland. Physiology of eating, Dietary, Toxicology, Sensory science

o 2008-2011: Engineer formation in food technology, ONIRIS, Nantes, France

Sciences and technology of industries and food science.

\section{Own publications (500)}

